Vol. 5 (1996): 491-501.

\title{
Finnish embryo transfer breeding program "ASMO": description of the goals and a summary of the results of initial selection
}

\author{
Esa A. Mäntysaari, Terhi Thuneberg-Selonen \\ Agricultural Research Centre of Finland, Institute of Animal Production, FIN-31600 Jokioinen, Finland, \\ e-mail: esa.mantysaari@mtt.fi
}

Kaija Hyppänen, Jarmo Juga

Finnish Animal Breeding Association, PO Box 40, FIN-01301 Vantaa, Finland

\begin{abstract}
In 1990 the organizations responsible for Finnish dairy breeding established an open nucleus multiple ovulation and embryo transfer (MOET) breeding program called ASMO. The aim was, besides to test effectiveness of MOET, to improve the protein to fat ratio in milk produced by Finnish Ayrshires but without sacrificing the progress in protein yield. The relative weights of traits were such that equal importance was assigned to protein $\%$ and protein yield. Negative weight was assigned to fat $\%$ to ensure it remained unaltered. The MOET work continued until 1994 after which the performance of selected animals has been monitored.

During the five years the scheme operated, 276 cows were flushed for embryos, and 2751 embryos were recovered, of which 1810 were transferable. More than 1600 embryos were transferred to recipients, and 813 calves were born. Eighty bull calves were sold for the artificial insemination test scheme. In December 1995 the first 125 ET daughters were evaluated with the national animal model program. Their mean estimated breeding values (EBVs) were +0.13 for protein $\%$ and -0.18 for fat $\%$ compared with the genetic base of progeny tested sires born in 1986-1988, and the protein yield EBVs were $12 \mathrm{~kg}$ above the genetic base. Despite the efficiency of selection, the program was discontinued in 1994. Due to the difficulty of maintaining sufficient control over donor animals, there were fewer than expected embryos per flush and also too few flushes per donor.
\end{abstract}

Key words: dairy cattle, MOET, nucleus breeding, protein $\%$, fat $\%$

\section{Introduction}

\section{Milk composition as a breeding goal}

The dairy industry world wide is in relatively good agreement about the goals for milk quality and milk composition: the milk produced should fulfil requirements for microbiological and organoleptic quality, and should contain a minimum of harmful residues. In the terms of composition of milk, it is widely agreed that the protein \% should be increased; no such consensus exists regarding fat $\%$. In the late 1980 s Finnish 


\section{AGRICULTURAL AND FOOD SCIENCE IN FINLAND}

Mäntysaari, E.A. et al. Finnish embryo transfer breeding program “ASMO”

Table 1. Results from milk recording for Finnish Ayrshire and Finnish Holstein-Friesian cows in 1988 and 1995 (National Board of Agriculture 1989, Association of Rural Advisory Centres 1996).

\begin{tabular}{lrrrrr}
\hline & \multicolumn{2}{c}{ Ayrshire } & & \multicolumn{2}{c}{ Holstein-Friesian } \\
\cline { 2 - 3 } \cline { 6 - 6 } & 1988 & 1995 & & 1988 & 1995 \\
\hline Cows, no & 230312 & 212754 & & 52299 & 57376 \\
Milk, kg & 5915 & 6880 & & 6009 & 7161 \\
Protein, kg & 190 & 228 & & 190 & 232 \\
Protein \% & 3.21 & 3.31 & & 3.15 & 3.24 \\
Fat, kg & 260 & 306 & & 247 & 294 \\
Fat \% & 4.40 & 4.44 & & 4.12 & 4.11 \\
Protein/fat ratio & 0.73 & 0.75 & & 0.76 & 0.79 \\
\hline
\end{tabular}

animal breeders and the dairy processing industry decided that the desired goal under Finnish conditions would be milk with a high protein to fat ratio $(\mathrm{P} / \mathrm{F})$ accompanied by as low a fat $\%$ as possible. Three reasons were given: i) The consumption of dairy products was clearly shifting towards low-fat products rich in protein. The average fat $\%$ of retail milk liquids was 3.32 in 1984 (Consumption of milk and milk products in Finland 1985), but only 2.83 in 1994 (Consumption of milk and milk products in Finland 1995). Consumption of cheese had steadily increased while that of butter had declined. In 1988 the average total consumption of butter was 8.2 $\mathrm{kg}$ per capita, down from $12.2 \mathrm{~kg}$ in 1980 (Central Statistical Office of Finland 1989). ii) The Finnish dairy industry had adopted a strategy to sell the surplus production on the world market in high premium cheese products. Naturally butter was exported as well, but cheese was favored

Table 2. Changes in weights of milk traits in total merit index of dairy bulls in Finland. Coefficients are relative to the standard deviations of the breeding value indices of corresponding traits.

\begin{tabular}{lccc}
\hline Year & Protein, kg & Protein \% & Fat \% \\
\hline $1988-1990$ & 1.0 & & \\
1990 & 0.8 & 0.3 & -0.3 \\
$1990-1991$ & 0.8 & 0.3 & -0.4 \\
$1991-1993$ & 1.0 & 0.3 & -0.4 \\
$1993-1996$ & 1.0 & 0.5 & -0.4 \\
1996 & 1.0 & 0.3 & \\
\hline
\end{tabular}

because of the higher price. iii) Compared with milk produced in Europe, Finnish raw milk had a low P/F, being 0.73 in Ayrshires in 1988 (Table 1). Such a ratio forces both cheese manufactures and dairies packing consumption milk to buy $25 \%$ more milk fat from producers than they sell in their main products.

In 1990 the breeding goal in the national artificial insemination (AI) program was chosen to directly change the protein $\%$ and fat $\%$ in milk. The change was towards lowering the fat content and slightly increasing the protein content of milk. The dry matter content of milk was thus expected to decline. The goal was implemented by including the milk composition traits in the total merit index (TMI) of bulls and cows. Table 2 lists the changes in weights of milk production traits in TMI of bulls since 1988. The weights are expressed relative to the standard deviations of the estimated breeding values (EBVs) of the traits.

Concerned about predictions that the official breeding program would result in a lower dry matter content of milk led the organizations involved with dairy breeding and research (Agricultural Research Centre - MTT; Finnish Animal Breeding Association - FABA) and milk marketing (Valio Co) in Finland to establish an open nucleus multiple ovulation and embryo transfer (MOET) breeding scheme (Nicholas and Smith 1983), which they called ASMO. The aim was, besides to study the effectiveness of MOET, to raise the $\mathrm{P} / \mathrm{F}$ in milk by improving the pro- 


\section{AGRICULTURAL AND FOOD SCIENCE IN FINLAND}

Vol. 5 (1996): 491-501.

tein $\%$, and thus to preserve the dry matter content. Relative weights were set for the traits, equal importance being given to protein $\%$ and protein yield. Negative weight was assigned to fat $\%$, high enough, however, to keep the fat content unaltered.

\section{Embryo transfer breeding schemes}

The MOET approach (Nicholas and Smith 1983) was introduced as an effective method for increasing the rate of genetic response. Compared with conventional AI breeding programs, MOET schemes operate on only a small number of animals. The improved genetic progress is mainly based on a short generation interval and thus fast turnover of animals. Because of the generation interval, returns are obtained sooner than with a progeny-testing system. Two types of scheme were defined: a juvenile scheme with a selection of animals in the age of 12 to 13 months on the basis of pedigree information, and an adult scheme with a selection of the females after the first lactation and the males that are selected on the basis of sib and dam performance.

Several refinements of nucleus breeding schemes, such as the open or closed nucleus, and the centralized or dispersed nucleus, have been suggested. The open nucleus utilizes outstanding females and AI bulls from the population outside the MOET scheme, whereas in the closed system, the donors are selected from nucleus herds exclusively. In the centralized operation, donors are housed in a testing station but in the dispersed scheme the donors remain housed on the private farms owning the cows (Colleau 1989). The additional returns expected from opening the nucleus have, however, been small, owing to the high genetic superiority of the nucleus, which leaves only little possibilities for elite recorded females to contribute back to the nucleus. Further, selection across the commercial population may be less accurate because of preferential treatment of favorite cows in the herds (Dekkers and Shook 1990, Meuwissen 1991a).
Centralized nucleus schemes have certain advantages. Fewer animals are involved, and thus the females in the central herd can be used more effectively. Comparisons among contemporaries are more reliable when made in the same environment and under the same management conditions and, moreover, the ET results may be better and less variable. Animals can be recorded more often, and special traits, for example feed intake, feed efficiency, milk protein variants and milking speed, can be measured (Nicholas and Smith 1983, Huizinga 1993). New ET technologies can be incorporated more rapidly and more effectively. A disadvantage of the centralized nucleus is the cost of establishing and running a nucleus herd. In addition, the disease risk of the nucleus may be greater, and in a selection based on testing station production, there is always a danger of genotype by environment interaction (Dekkers 1992).

In nucleus schemes the genetic response may be limited by an increased rate of inbreeding. The annual inbreeding rate depends on the number of parents selected per generation, the generation interval and the genetic relationship between selected parents (Falconer 1989). High levels of inbreeding are detrimental because of the effects on production and reproduction performance. Although more effective in genetic progress, the juvenile scheme leads to higher rates of inbreeding than the adult scheme (Nicholas and Smith 1983, Woolliams 1989, Meuwissen 1991b). This is mainly due to the shorter generation interval but also due to selection based on family indices.

On the basis of stochastic simulations, Juga and Mäki-Tanila (1987) claimed that the original estimates of the effectiveness of MOET schemes were too optimistic when compared with AI breeding programs based on progeny testing. Their findings were confirmed by many others (e.g. Toro and Silió 1989, Ruane and Thompson 1991). One theoretical reason for the reduction in response is the loss of genetic variance due to linkage disequilibrium (Bulmer 1971). Ruane and Thompson (1991), however, questioned whether the reduction in genetic var- 


\section{AGRICULTURAL AND FOOD SCIENCE IN FINLAND}

\section{Mäntysaari, E.A. et al. Finnish embryo transfer breeding program "ASMO"}

iance due to selection presents such a problem in practice as has been observed in simulations. Moreover, the same loss of genetic variance can be shown to affect the response achieved in progeny testing schemes (e.g. Meyer and Smith 1990).

We describe here ASMO, a Finnish MOET scheme that ran from 1990 to 1994 . We document the aims of the program, the selection practiced, and the genetic progress predicted and achieved. In the end, the scheme as such was carried on through the first generation selection only. The reasons for the discontinuation will be discussed. The technical outcome of ET performance will be published later.

\section{Material and methods}

\section{Selection of first generation animals}

The ASMO breeding scheme was designed to include some 100 donor cows per year. These would be selected using national animal model (AM) breeding value indices for protein yield, protein $\%$ and fat $\%$. Selection of the first generation bulls and donor cows started in fall 1990. The donors were selected from milk recorded cows, and the bulls from progeny tested AI bulls whose total merit index qualified them as elite sires. Selection was based on the ASMO index (I), which was calculated as follows:

$I_{\text {cow }}=($ protein $-\%$ index $)-0.6 \times($ fat $-\%$ index $)+$ $0.4 \times($ protein yield index $)$

and

$I_{\text {bull }}=0.7 \times($ protein $-\%$ index $)-0.4 \times($ fat $-\%$ index $)+0.5 \times \mathrm{TMI}$,

where protein- $\%$, protein yield and fat- $\%$ indices are from the AM evaluations, and TMI is the total merit index of bulls. The weights in the index were chosen to provide equal progress (relative to genetic variance) in protein yield and the corresponding percentage while keeping the fat \% constant or so that it decreased slightly. As all published EBVs are standardized by setting the standard deviation of active bulls to ten, the weights were comparable across the traits. In the evaluations made in December 1995, the corresponding standard deviations of EBVs for protein yield, protein $\%$ and fat $\%$ were $10 \mathrm{~kg}$, $0.13 \%$ and $0.29 \%$ for Ayrshires and $10 \mathrm{~kg}$, $0.12 \%$ and $0.28 \%$ for Holstein-Friesians, respectively. The TMI for bulls included the EBVs for percentages (Table 2, 1990-1994) and also some secondary traits. In 1993, for instance, these non-production indices were female fertility (weight 0.3 ) and udder health (weight 0.3 ). When the coefficients of production indices in TMI and in $\mathrm{I}_{\text {bull }}$ are combined the relative weights are 0.5 for protein, 0.95 for protein $\%$, and -0.6 for fat $\%$.

The final selection was made by breeding advisers of the FABA, only cows fulfilling the criteria for udder and leg conformation were approved for the scheme. The cows selected were superovulated, inseminated by selected bulls and flushed for embryos. Each donor was intended to produce eight offspring. On the basis of expected ET results, this was thought to be achieved with an average of three flushings. The scheme was planned to continue after the first generations as an open dispersed nucleus with adult cows. In the first generations a large proportion of the animals were expected to come from the AI population, but later the donor cows would automatically be selected from the nucleus. The initial selection covered Ayrshire cows only. However, during the operation the Finnish Holstein-Friesian breeders expressed a wish to participate in the scheme and to obtain the same genetic change in milk composition as was foreseen for the Ayrshire breed. In 1993, then Holstein-Friesian donors were admitted to the scheme. Besides flushing own Finnish HolsteinFriesian cows, Holstein-embryos were also imported from the Netherlands. All Holstein embryos were transferred at a quarantine station because of animal health regulations, and the purchased material was distributed to commercial farms as pregnant heifers. 


\section{AGRICULTURAL AND FOOD SCIENCE IN FINLAND}

Vol. 5 (1996): 491-501.

\section{Arrangements for ET work}

As part of the decentralized strategy, the flushing and embryo transfers of Ayrshires were carried out on private farms. Superovulation treatments were arranged through local veterinarians, after which the cows were inseminated by selected bulls. Mating plans for chosen animals were coordinated centrally. The farmer chose which bull to use in insemination from a list of three recommended for each donor. The donors were flushed and the embryos transferred by four veterinarians of the Embryo Centre Co. (Vantaa, Finland). Fresh embryos were transferred to recipients on the same or neighbouring farms, and frozen embryos were passed to other farmers in the scheme at a nominal price. Farmers buying embryos had to agree that any offspring would be used in ASMO program. Direct cost of flushing and compensation for flushing were paid to the farmer by the project.

\section{Results}

By 1995, 293 (268 Ayrshire and 25 HolsteinFriesian) cows had been selected for the scheme. A few cows (18) were accepted twice in consecutive years. Early in the study no special attention was paid to the phenotypic production level of the donor cows. This, however, lead to problems with the further marketing of frozen embryos. Therefore, after 1991 it was further re- quired that only cows reaching the average national production level qualified for selection. This rule, and a strict selection on AM indices, resulted in a group of donor cows with life time annual average production of $8206 \mathrm{~kg}$, a protein \% of 3.52 and a fat $\%$ of 4.21 . The P/F of the cows selected was 0.84 . The number of lactations of the cows ranged from one to eight, but the majority of donors were in third or fourth parity. Table 3 presents the mean lifetime annual average production records of Ayrshire and Holstein-Friesian donors in Finland. As selection was mainly based on AM indices the selection differential achieved is best verified using the means of the donors' AM indices. These are presented for the Ayrshire donors selected in different years in Table 4 and for Finnish HolsteinFriesians in Table 5. In 1994, there were only three Ayrshire and six Holstein-Friesian donors.

The mean of published indices of all Ayrshire donors, compared with the genetic base of progeny tested sires born in 1986-88, was 111 for both protein yield and protein \% (Table 4). The best Ayrshires had a protein yield index of up to 143 and the best Holstein-Friesians of 139 (Tables 4 and 5). The mean protein- $\%$ and fat- $\%$ EBVs for Ayrshire cows born in the 1980s were generally slightly below 100 (Fig. 1a and Tables 4 and 5). For protein production the mean of EBV indices of candidate cows was 92 in 1990, increasing to 98 in 1993-1994 (Tables 4 and 5). The minimum index for protein yield at the moment of selection was generally $110-120$, but over the years some of the EBVs have declined as the cows have got more lactations and other

Table 3. Lifetime annual average production of 293 cows in ASMO project.

\begin{tabular}{lrrrrrrrrr}
\hline & \multicolumn{3}{c}{ Ayrshire $(\mathrm{n}=268)$} & & & \multicolumn{2}{c}{ Holstein-Friesian $(\mathrm{n}=25)$} \\
\cline { 2 - 3 } & mean & $\min$ & $\max$ & & mean & $\min$ & $\max$ \\
\hline Milk, kg & 8122 & 5668 & 13087 & & 9106 & 7190 & 11541 \\
Protein, kg & 286 & 210 & 449 & & 314 & 240 & 393 \\
Protein \% & 3.52 & 3.10 & 4.00 & & 3.44 & 3.20 & 3.80 \\
Fat, kg & 346 & 234 & 535 & & 335 & 258 & 400 \\
Fat \% & 4.26 & 2.70 & 5.70 & & 3.69 & 3.10 & 4.70 \\
Protein/Fat ratio & 0.83 & 0.63 & 1.37 & & 0.93 & 0.77 & 1.07 \\
\hline
\end{tabular}




\section{AGRICULTURAL AND FOOD SCIENCE IN FINLAND}

Mäntysaari, E.A. et al. Finnish embryo transfer breeding program “ASMO”

Table 4. Animal model indices of 268 Ayrshire cows for milk traits in ASMO project (Base = Ayrshire bulls born 19861988) averaged by year of selection. Estimated superiority of selected donors over available cow population given in parentheses.

\begin{tabular}{|c|c|c|c|c|c|c|c|c|c|c|c|c|c|c|c|c|}
\hline & \multicolumn{4}{|c|}{$1990(n=14)$} & \multicolumn{4}{|c|}{$1991(n=122)$} & \multicolumn{4}{|c|}{$1992(n=75)$} & \multicolumn{4}{|c|}{$1993-1994(n=57)$} \\
\hline & units ${ }^{1}$ & inde $x^{2}$ & $\min$ & $\max$ & units & index & $\min$ & $\max$ & units & index & $\min$ & $\max$ & units & index & $\min$ & $\max$ \\
\hline $\begin{array}{l}\text { Milk, kg } \\
\text { superiority }^{3}\end{array}$ & +71 & $\begin{array}{l}102 \\
(+8)\end{array}$ & 88 & 127 & +35 & $\begin{array}{l}101 \\
(+5)\end{array}$ & 81 & 129 & +176 & $\begin{array}{l}105 \\
(+8)\end{array}$ & 81 & 138 & +212 & $\begin{array}{l}106 \\
(+6)\end{array}$ & 88 & 126 \\
\hline $\begin{array}{l}\text { Protein, kg } \\
\text { superiority }^{3}\end{array}$ & +14 & $\begin{array}{c}114 \\
(+22)\end{array}$ & 98 & 143 & +9 & $\begin{array}{c}109 \\
(+15)\end{array}$ & 83 & 133 & +13 & $\begin{array}{c}113 \\
(+17)\end{array}$ & 92 & 142 & +14 & $\begin{array}{c}114 \\
(+16)\end{array}$ & 94 & 140 \\
\hline $\begin{array}{l}\text { Protein } \% \\
\text { superiority }\end{array}$ & +.21 & $\begin{array}{c}116 \\
(+16)\end{array}$ & 107 & 130 & +.15 & $\begin{array}{c}111 \\
(+16)\end{array}$ & 91 & 128 & +.11 & $\begin{array}{c}110 \\
(+10)\end{array}$ & 95 & 130 & +.12 & $\begin{array}{l}109 \\
(+9)\end{array}$ & 89 & 123 \\
\hline $\begin{array}{l}\text { Fat } \% \\
\text { superiority }^{3}\end{array}$ & +.06 & $\begin{array}{l}102 \\
(+5)\end{array}$ & 91 & 115 & -.09 & $\begin{array}{l}97 \\
(-1)\end{array}$ & 74 & 119 & -.15 & $\begin{array}{l}95 \\
(-3)\end{array}$ & 73 & 117 & -.21 & $\begin{array}{c}93 \\
(-3)\end{array}$ & 77 & 108 \\
\hline
\end{tabular}

' Index in original units.

${ }^{2}$ Finnish animal model indices are standardized for a mean of 100 and a standard deviation of 10 for the base bulls.

${ }^{3}$ (Mean of selected animals) - (Mean of all Ayrshire cows in lactation 1-3).

Table 5. Average animal model indices of 25 Holstein-Friesian cows for milk traits in ASMO project 19931994 (Base $=$ Holstein-Friesian bulls born 1986-88). Estimated superiority of selected donors over available cow population given in parentheses.

\begin{tabular}{lcccc}
\hline & units $^{1}$ & index $^{2}$ & $\min$ & $\max$ \\
\cline { 2 - 4 } Milk, kg & +285 & 108 & 96 & 128 \\
superiority & & $(+10)$ & 116 & 139 \\
Protein, kg & +17 & $(+18)$ & 100 & 133 \\
superiority & & 112 & 94 & 107 \\
Protein \% & +.15 & $(+10)$ & 82 & \\
superiority & & 91 & & \\
Fat $\%$ & -.25 & $(-8)$ & & \\
superiority $^{3}$ & & & & \\
\hline
\end{tabular}

' Index in original units.

${ }^{2}$ Finnish animal model indices are standardized for a mean of 100 and a standard deviation of 10 for the base bulls.

${ }^{3}$ (Mean of selected animals) - (Mean of all Holstein Friesian cows in lactation 1-3).

data have become available. The same holds for protein-\% EBVs, even though very low indices were also found in animals that had an exceptionally low fat- $\%$ index. In the first two years of selection the emphasis was clearly on protein $\%$; later, selection shifted more towards high protein yield and a low fat \%. Although no clear pressure downward was planned for the fat $\%$, it did in fact decline slightly (the mean fat- $\%$ index of selected cows was 96, Table 4). The change in fat $\%$ was particularly marked among the Holstein-Friesians (index 91, Table 5), where the selected animals were more clearly of the conventional bull dam type.

Of the 293 cows selected for the scheme, 17 did not respond to superovulation at all and 276 were superovulated and flushed a total of 454 times; $64 \%$ were first flushings, $28 \%$ second flushings and only $8 \%$ third flushings. The total number of embryos recovered was 2751 . On average, $66 \%$ (1810) of the embryos recovered were transferable, thus yielding an average of 
Vol. 5 (1996): 491-501.
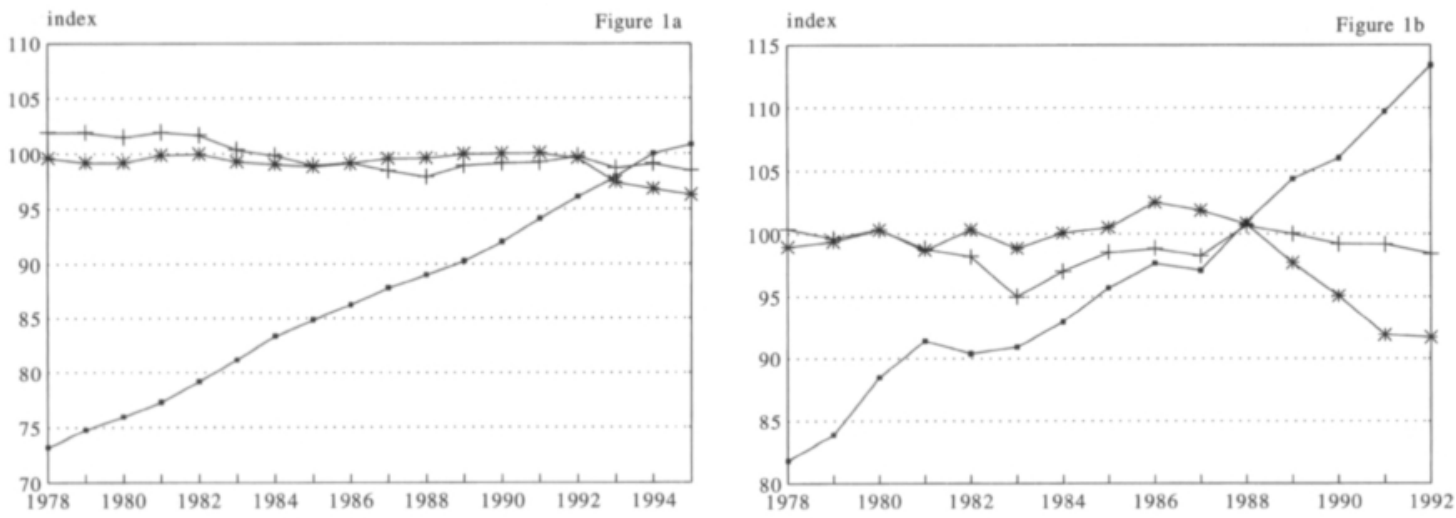

Fig. 1. Breeding value estimates of Ayrshire cows (1a) and bulls (1b) for protein production ( $-\mathbf{a}-)$, protein \% ( - + -), and fat \% (- - - displayed by birth year. Estimates are based on evaluations made in 1996 and standardized by setting the mean and standard deviation of bulls born in 1986-1988 at 100 and 10, respectively.

4.0 transferable embryos per flush. The average number of transferable embryos per superovulated cow was 6.6. Transfer results are available on 746 fresh embryos and 868 frozen embryos with success rates of $60.3 \%$ and $43.0 \%$, respectively.

In the embryo transfers, 31 different sires were used for Ayrshire donors and eight different sires for Holstein-Friesian donors. Pedigree indices were calculated for the recovered embryos using the EBVs for both the parents (Table 6). In terms of standardized indices, the em- bryos were on average comparable in protein yield and protein \%. A certain trend towards the former national breeding goal can be seen, i.e. protein yield and a low fat $\%$ were emphasized more than in donor selection, indicating that cows of the conventional bull dam -type were used to produce more embryos than were the alternative breeding goal -type donors. Another reason is that the use of bulls was not as well balanced as planned, sires with a high TMI producing more progeny.

The information collected show that 424 bull

Table 6. Comparison of animal model indices' ${ }^{\prime}$ of Ayrshire ASMO embryos, ASMO first parity cows, daughters of bull dams and all first parity cows calved in 1994.

\begin{tabular}{lcccr}
\hline & $\begin{array}{c}\text { ASMO } \\
\text { embryos }\end{array}$ & $\begin{array}{c}\text { ASMO first } \\
\text { parity cows }\end{array}$ & $\begin{array}{c}\text { Bull dam } \\
\text { daughters }\end{array}$ & $\begin{array}{c}\text { First parity } \\
\text { cows }\end{array}$ \\
\cline { 2 - 5 } Number & 1574 & 125 & 101 & 68698 \\
Milk index & 104 & 104 & 112 & 102 \\
Protein index & 111 & 112 & 116 & 101 \\
Protein-\% index & 110 & 110 & 102 & 100 \\
Fat-\% index & 97 & 94 & 90 & 95 \\
TMI & 19.6 & 19.8 & 21.7 & 2.6 \\
Max TMI & 40 & 48 & 41 & \\
\hline
\end{tabular}

' Finnish animal model indices are standardized for a mean of 100 and a standard deviation of 10 for the base bulls born in 1986-1988.

${ }^{2} \mathrm{TMI}=1.0 \times($ protein yield index $)+0.5 \times($ protein $-\%$ index $)-0.4 \times($ fat $-\%$ index $)+0.2 \times($ somatic cell count index $)+0.3 \times($ udder conformation index $)$ 


\section{Mäntysaari, E.A. et al. Finnish embryo transfer breeding program "ASMO"}

calves and 389 heifer calves were born alive. During the scheme, AI cooperatives bought 80 ASMO bull calves; of the 75 that completed the growth test at the performance test station, 42 were accepted for AI usage, and 33 were removed due to either poor growth capacity or bad conformation. The daughters of the bulls born from the first transfers, made in 1990, were in their first lactation in 1995 and will give an accuracy of prediction high enough that their EBVs are to be published in 1996.

Production information is now available on 125 of the daughters from the first embryos transferred in 1990 and 1991. Their AM indices agree well with the expectations (Table 6). The average protein yield index was 112 and the protein$\%$ index 110 . For comparison, Table 6 also lists the averages of indices for all the first calvers and for daughters of official bull dams that have calved first time in 1994. In terms of index points, the genetic superiority of the first ASMO daughters to all first calvers was 11 points for protein yield, 10 points for protein $\%$, and -1 point for fat $\%$. These can be transferred to their original units using the standard deviations given earlier. The index values correspond to $11 \mathrm{~kg}$, $+0.12 \%$-units, and $-0.03 \%$-units in protein yield, protein $\%$, and fat $\%$, respectively. Compared with the genetic base of active AI bulls, the selection differences were $+12 \mathrm{~kg}$ for protein yield and $+0.13 \%$ for protein $\%$. However, for fat $\%$ the shift was downwards, $-0.18 \%$ units, as compared with base bulls. Thus, for fat $\%$ the national breeding policy and the former TMI for bulls have clearly resulted in a larger decreasing trend in EBVs of all primiparous cows, thus leaving ASMO animals above the current female population. The distinction in bull dam daughters and ASMO daughters is clear in the protein-\% EBVs, which are lower in daughters of bull dams. Interestingly, the ASMO daughters are comparable to the bull dam daughters in the cow TMI. The average for the first generation ASMO cows was +20 but for bull dam daughters +22 . The best animal in the ASMO daughter group had a TMI as high as +48 . The TMI for cows in 1995 gave a weight of 1.0 for protein yield, 0.5 for protein $\%,-0.4$ for fat $\%$, 0.2 for somatic cell count and 0.3 for udder conformation EBVs.

\section{Discussion}

One of the main purposes of the ASMO project was to investigate the feasibility of changing the $\mathrm{P} / \mathrm{F}$ in milk by increasing the protein content. The results showed that it is indeed possible. In the Ayrshire breed, the expected genetic superiority of the first generation ASMO calves will be $+11 \mathrm{~kg}$ in protein yield, +0.13 units in protein $\%$, and -0.09 units in fat $\%$, when calculated as the mean of all 1574 embryos collected and compared with current mean of progeny tested sires. On the basis of these projected changes in milk yield and fat \%, production of butter fat per cow in the selected material should be slightly below the population average. Thus, the new $\mathrm{P} / \mathrm{F}$ would be expected to reach 0.79 , which is a clear improvement on the 0.75 found in the milk recorded Ayrshire population. Extrapolated to Finland's total milk production, such a change would mean that, at a fixed milk protein production, about 4.5 million $\mathrm{kg}$ less milk fat would be produced. Some of this change will be disseminated to the commercial population through AI sires. The first daughters of ASMO young bulls calved in the latter half of 1995. The impact of the program becomes even larger if some of the ASMO bulls are selected to be used as elite sires.

Published results on realized MOET schemes are sparse, and the majority of them concern the Holstein breed. Lohuis et al. (1993) reported the results of a dispersed hybrid nucleus program. Bulls originating from this Canadian TEAM (Total Evaluation of Animals with MOET) project provided approximately one-third of the young bulls entering Canadian progeny testing programs. The Genus project in the UK and the Delta project in the Netherlands have more commercial ambitions. Genus seeks to maximize the 


\section{AGRICULTURAL AND FOOD SCIENCE IN FINLAND}

Vol. 5 (1996): 491-501.

level of genetic merit for overall economic efficiency (Christie et al. 1992), and Delta, which has been running since the late 1980 s, was founded to a large extent to rationalize the optimal use of genetic material from different sources, North American, Dutch or other European (Huizinga 1993), but has since become a leading provider of international Holstein breeding material. Liboriussen and Christensen (1990) provided data on an experimental MOET scheme in Denmark concerning all four Danish dairy breeds: Red Danish, Danish Black and White, Danish Jersey and Danish Red and White. The nucleus herd was established to test the utilization of new technologies and to improve traits difficult to measure under field conditions.

The ASMO study showed that the management of an open nucleus MOET program is problematic because of insufficient control over the animals selected. In the original plan, the target was eight pregnancies per selected donor, but an average of only 3.0 was achieved. This resulted from the lack of interest shown by farmers in allowing their cows to be flushed more than once. Only 35 of 276 participating cows were flushed three times. The reluctance to permit embryo transfer was caused by concern over the possible decrease in milk yield, prolonged calving interval, risks for reproductive health, cost of the superovulation, etc. These fears, compounded by the possibility that superovulation would not result in any transferable embryos, seemed to generate too great a risk for the small scale producer. These suspicions were confirmed by a survey conducted among the owners of donor cows (Nousiainen et al. 1993).

In the original strategy, the selection of first generation donors was planned to continue until the offspring of animals selected in 1990 would have their first lactation records, and the second generation animals could be selected. However, selection of the future generations was also to be based on national breeding value indices, and the cows with high $\mathrm{I}_{\text {cow }}$ could have been selected irrespective of whether they were offspring of ASMO or commercial cows. The scheme as such was discontinued in 1994, because of the high cost of ET work compared with the results achieved. It had nevertheless shown that, with a special program, a new breeding goal, e.g. milk composition, can be effectively selected for. On the other hand, it also suggested that the efficiency of superovulation based on ET is not yet in the level of practical applicability. The latter interacts with managemental problems with open nucleus MOET, if the final decision regarding use of the donor cow remains to be made by the owner. Practical experience of the Genus MOET breeding scheme also shows that the failure to produce large numbers of embryos per donor will pose particular challenges. Only $11 \%$ of the donors achieved the target of 16 freezable embryos after the first flush and $25 \%$ after the third flush (Christie et al. 1992).

Clearly the alternative breeding material produced cannot be sufficiently utilized either nationally or internationally if the top nucleus cows are not used more effectively. Developments in reproductive technology such as in vitro embryo production (IVP), cloning, embryo sexing, and splitting will improve the technical efficiency of ET (Gordon 1994). Control over the use of selected donors also needs to be improved. Judging by the problems encountered in the management of the dispersed nucleus it would seem that a centralized MOET herd would result in better efficiency in the use of selected animals. The centralized scheme would also permit new reproductive techniques to be exploited.

Acknowledgements. The ASMO program was administered by Agricultural Research Centre of Finland, Finnish Animal Breeding Association - FABA and Valio Co. We are grateful to the Agriculture Data Processing Centre and the Embryo Centre Co. for their cooperation and to the Ministry of Agriculture and Forestry for financial support. 
Mäntysaari, E.A. et al. Finnish embryo transfer breeding program "ASMO"

\section{References}

Association of Rural Advisory Centres 1996. Results of the milk recording in Finland. Maaseutukeskusten Liitto, publication 904, Helsinki, Finland. p. 24-25.

Bulmer, M.G. 1971. The effect of selection on genetic variability. American Naturalist 105: 201-211.

Central Statistical Office of Finland 1989. Statistical yearbook of Finland 84: 313.

Christie, W.B., McGuirk, B.J., Strahie, R.J. \& Mullan, J.S. 1992. Practical experience with the implementation of a MOET breeding scheme with dairy cattle. Annales de Zootechnie 41: 347-352.

Colleau, J.J. 1989. The genetics of dairy MOETs. In: Kalm, E. \& Liboriussen, T. (eds.). New selection schemes in cattle: nucleus programmes. Pudoc Wageningen, Netherlands. p. 55-63.

Consumption of milk and milk products in Finland 1985. Ravitsemuskatsaus 7(1): 7. (In Finnish).

- 1995. Ravitsemuskatsaus 17(1): 31. (In Finnish).

Dekkers, J.C.M. 1992. Structure of breeding programs to capitalize on reproductive technology for genetic improvement. Journal of Dairy Science 75: 2880-2891.

- \& Shook, G.E. 1990. Genetic and economic evaluation of nucleus breeding schemes for commercial artificial insemination firms. Journal of Dairy Science 73: 1920-1937.

Falconer, D.S. 1989. Introduction to quantitative genetics. Longman Ltd., New York (3rd ed.). 438 p.

Gordon, I. 1994. Laboratory production of cattle embryos. University Press Cambridge. 640 p.

Huizinga, H. 1993. Delta: speed, reliability and competition. Veepro Holland 17: 20-21.

Juga, J. \& Mäki-Tanila, A. 1987. Genetic change in a nucleus breeding dairy herd using embryo transfer. Acta Agriculturae Scandinavica 37: 511-519.

Liboriussen, T. \& Christensen, L.G. 1990. Experiences from implementation of a MOET breeding scheme for dairy cattle. Proceedings of the 4 th World Congress on
Genetics Applied to Livestock Production, Edinburgh, vol 14: 66-69.

Lohuis, M.M., Smith, C. \& Dekkers, J.C.M. 1993. MOET results from a dispersed hybrid nucleus programme in dairy cattle. Animal Production 57: 369-378.

Meuwissen, T.H.E. 1991a. The use of increased female reproductive rates in dairy cattle breeding schemes. Animal Production 52: 21-31.

- 1991b. Expectation and variance of genetic gain in open and closed nucleus and progeny testing schemes. Animal Production 53: 133-141.

Meyer, K. \& Smith, C. 1990. Comparison of theoretical and simulated equilibrium genetic response rates with progeny testing in dairy cattle. Animal Production 50:207212.

National Board of Agriculture 1989. Statistics on the milk recording 1988. Maatilahallitus, Helsinki, Finland. 47 p. (In Finnish).

Nicholas, F.W. \& Smith, C. 1983. Increased rates of genetic change in dairy cattle by embryo transfer and splitting. Animal Production 36: 341-353.

Nousiainen, S., Pölönen, K. \& Varis, J. 1993. Embryo transfer - future cattle breeding? Research report. Agricultural School of Kitee. 38 p. (In Finnish).

Ruane, J. \& Thompson, R. 1991. Comparison of simulated and theoretical results in adult MOET nucleus schemes for dairy cattle. Livestock Production Science 28: $1-20$,

Toro, M. \& Silió, L. 1989. Genetic simulation of juvenile MOET breeding nucleus schemes in dairy cattle. In: Kalm, E. \& Liboriussen, T. (eds.). New selection schemes in cattle: nucleus programmes. Pudoc Wageningen, Netherlands. p. 64-71.

Woolliams, J.A. 1989. Modifications to MOET nucleus breeding schemes to improve rates of genetic progress and decrease rates of inbreeding in dairy cattle. Animal Production 49: 1-14. 
Vol. 5 (1996): 491-501.

\title{
SELOSTUS
}

\section{Alkionsiirtojalostusohjelma "ASMO", sen tavoitteet ja yhteenveto alkuvalinnan tuloksista}

\author{
Esa A. Mäntysaari, Terhi Thuneberg-Selonen, Kaija Hyppänen ja Jarmo Juga \\ Maatalouden tutkimuskeskus ja Osuuskunta Kotieläinjalostuskeskus FABA
}

Vuonna 1990 käynnistyneessä ASMO-projektissa (alkionsiirtojalostusohjelma maidon koostumuksen optimoimiseksi) oli tavoitteena tutkia avoimeen ydinkarjaan perustuvan alkionsiirto-ohjelman soveltuvuutta maidon koostumuksen muuttamiseen. Lisäksi oli tarkoitus nostaa maidon valkuaispitoisuutta muuttamatta rasvapitoisuutta. Ohjelman toteuttivat Maatalouden tutkimuskeskus, KotieläinjalostuskeskusFABA ja Valio Oy. Maa- ja metsätalousministeriö rahoitti osan ohjelman kustannuksista.

Viisivuotisessa projektissa oli nk. alkuvalintavaihe eli perussukupolven vanhempien valinta. Valinta tehtiin karjantarkkailulehmien ja keinosiemennyssonnien joukosta valkuaissuhdevalintaindeksin (VSI) perusteella. Lehmien VSI:ssä painotettiin valkuaispitoisuus-, rasvapitoisuus- ja valkuaistuotosindeksien poikkeamia rotukeskiarvosta painokertoimilla 1,0,0,6 ja 0,4 . Sonnien VSI:ssä olivat mukana valkuaisja rasvapitoisuusindeksit ja kokonaisjalostusarvo painokertoimilla $0,7,-0,4$ ja 0,5 . Valkuaissuhdevalintaindeksien avulla projektiin valittiin 293 lehmää ja 39 sonnia. Alkuvalinnassa onnistuttiin hyvin, sillä ASMO-lehmien maitotuotos oli $106 \mathrm{~kg}$, valkuaistuotos $11 \mathrm{~kg}$ ja valkuaispitoisuus 0,15 prosenttiyksikköä parempi kuin ayrshirelehmillä keskimäärin.
Kaikkiaan ASMO-projektissa tehtiin 454 huuhtelua 276 lehmälle. Huuhteluiden alkiosaalis kohosi 2751 alkioon $(6,1 /$ huuhtelu), joista oli siirtokelpoisia 1810 (4,0/huuhtelu). Tammikuuhun 1996 mennessä on syntynyt 389 lehmävasikkaa ja 424 sonnivasikkaa, joista 80 ostettiin keinosiemennyskäyttöön. Joulukuun 1995 eläinmalliarvostelussa ensimmäiset 125 ASMO-hiehoa saivat omat jalostusarvot: ASMO-tyttärien maidon valkuaispitoisuus on 0,13 prosenttiyksikköä rotukeskiarvon yläpuolella ja rasvapitoisuus 0,18 prosenttiyksikköä rotukeskiarvon alapuolella.

Alkuperäisen suunnitelman mukaan tavoitteena oli huuhdella luovuttajalehmiä kolme kertaa tuottaen niille vähintään 8 jälkeläistä. Tämä tavoite jäi saavuttamatta: siirtokelpoisten alkioiden määrä lehmää kohti oli 6,6. Peläten maitotuotosten mahdollista alenemista, poikimavälin pidentymistä, hedelmällisyyshäiriöitä ja alkionsiirrosta aiheutuvia kustannuksia karjanomistajat olivat haluttomia luovuttamaan lehmänsä huuhdeltavaksi riittävän monta kertaa. Kokonaisuudessaan ASMO-projekti osoitti, että alkionsiirtojalostusohjelmalla voidaan päästä tehokkaasti jalostustavoitteisiin, mutta alkionsiirtojen tuloksellisuus ja valittujen eläinten tehokas käyttö ns. hajautetussa ydinkarjamallissa on heikko. 